Article

\title{
Demographic Resilience in Local Systems: An Empirical Approach with Census Data
}

\author{
Andrea Colantoni ${ }^{1}{ }^{\infty}$, Rares Halbac-Cotoara-Zamfir ${ }^{2}{ }^{\infty}$, , Cristina Halbac-Cotoara-Zamfir ${ }^{3}$, \\ Pavel Cudlin ${ }^{4}$, Luca Salvati ${ }^{5, *}$ and Antonio Gimenez Morera ${ }^{6}$ \\ 1 Department of Agricultural and Forestry Sciences (DAFNE), Tuscia University, Via San Camillo de Lellis, \\ I-01100 Viterbo, Italy; colantoni@unitus.it \\ 2 Department of Overland Communication Ways, Foundation and Cadastral Survey, Politehnica University \\ of Timisoara, 1A I. Curea Street, 300224 Timisoara, Romania; rares.halbac-cotoara-zamfir@upt.ro \\ 3 Center for Career Counselling and Guidance, Politehnica University of Timisoara, 2nd Victoriei Square, \\ 300006 Timisoara, Romania; cristina.halbac@upt.ro \\ 4 Global Change Research Institute CAS, Lipova 9, 37005 Ceske Budejovice, Czech Republic; \\ cudlin.p@czechglobe.cz \\ 5 Department of Economics and Law, University of Macerata, Via Armaroli 43, I-62100 Macerata, Italy \\ 6 Departamento de Economia y Ciencias Sociales, Universitat Politècnica de València, Cami de Vera S/N, \\ ES-46022 València, Spain; angimo1@doctor.upv.es \\ * Correspondence: luca.salvati@unimc.it; Tel.: +39-0661-5710; Fax: +39-066-157-1036
}

Received: 11 August 2020; Accepted: 16 September 2020; Published: 19 September 2020

check for updates

\begin{abstract}
This study estimates demographic resilience in local socioeconomic systems of Southern Europe using long-term population dynamics. We assume attractive places with a continuously expanding (resident) population as 'demographically resilient', and locations experiencing a persistent decline of population as more fragile to external shocks. Based on these premises, a comprehensive assessment of demographic resilience in more than 1000 municipalities along the urban-rural gradient in Greece, a Mediterranean country with marked regional disparities, was carried out between 1961 and 2011. Municipalities were considered representative of homogeneous local communities, especially in rural areas. The results of non-parametric correlations suggest how basic geographical gradients (coastal-inland and urban-rural) have significantly influenced the demographic resilience of Greek municipalities. These findings outline two contrasting spatial patterns that reflect (i) continuous expansion of peri-urban local communities and (ii) a particularly intense rural shrinkage, linking depopulation to land abandonment and scarce accessibility of inland districts. While long-term population growth in Greece has progressively re-shaped the intrinsic divide in urban and rural areas, the traditional gap in central and peripheral districts is still reflected in the spatial polarization between the 'demographically resilient', socially dynamic coastal locations and the 'demographically fragile' inland, economically marginal places. These results indicate the persistence of a center-periphery model characterizing long-term settlement expansion in Greece, with spatial patterns delineating 'resilient' and 'fragile' districts based essentially on infrastructures, accessibility, and amenities.
\end{abstract}

Keywords: population dynamics; urban-rural divide; economic downturns; depopulation; Mediterranean

\section{Introduction}

Analysis of socioeconomic systems' complexity focuses on the intrinsic dynamics characteristic of highly open, internally heterogeneous, and relationally linked local communities [1-4]. To evaluate such dynamics, interpretative frameworks oriented towards Complex Adaptive System (CAS) thinking were proposed and widely used in practice [5-7]. This paradigm assumes the inseparability and intertwined functioning of local socioeconomic systems, a nonlinear linkage among their basic components, and the 
existence of positive and negative feedback mechanisms accounting for both extrinsic and intrinsic system dynamics [8]. In a CAS framework, the notion of socioeconomic resilience-reflecting the ability of a local system to avoid being locked into a low-level equilibrium-contributes to envisioning the complete transition toward a 'better performing' equilibrium [9-11]. After experiencing a shock, local resilience is linked with the extent to which a socioeconomic system returns to the status quo (estimated through pre-crisis growth rates of, e.g., output, employment, population, or other relevant variables). Resilience explicitly (or implicitly) depends on different territorial forces [12-14], whose impact is, in turn, reflected in the spatial organization of a given region or district [15-18]. For this reason, the (apparent or latent) linkages between resilience and the territorial organization of a given socioeconomic system have been increasingly investigated, often focusing on specific areas or local communities [19].

As it is evaluated using different approaches from various disciplinary perspectives [20], resilience is considered an intrinsic property of socioeconomic systems. While implementing resilience metrics that address a broad range of measurement issues is a rather complicated task, resilient and non-resilient systems can be identified by examining their socioeconomic performance over a sufficiently long time period that covers one (or more) external shock (s), e.g., by using pertinent indicators [21]. Criteria related to appropriate coverage, simplicity and ease of comprehension, affordability, suitability for international comparisons, and transparency were considered appropriate for a permanent monitoring of socioeconomic resilience [22]. In these regards, population expansion (or decline) has been often associated with socioeconomic resilience of local systems [23-25]. More specifically, long-term population dynamics reflect the importance of the 'demographic resilience' dimension in a broader socioeconomic perspective [26].

Demographic resilience can be defined as the ability of local socioeconomic systems to resist and recover from alterations in their population dynamics and structure [27]. Changes in population size are considered a direct measure of demographically resilient (or un-resilient) development paths in a given area, community, or, generally speaking, socioeconomic system [28]. As a matter of fact, small-scale demographic growth (indirectly) resembles the capacity of a local system to respond to disturbances and to reorganize [29], undertaking change to preserve functions, structure, and feedbacks, as well as to promote future development options by continuously attracting populations [26]. By contrast, a continuous demographic decline brings local systems toward collapse, weakening the intrinsic capacity to evolve toward different socioeconomic paths and dynamic equilibriums [30].

Based on these premises, demographic resilience is a pivotal issue deserving further investigation and a dedicated policy regulation [31] because "when countries find ways to harness population dynamics, they enhance their 'demographic resilience' and find ways to plan for the shocks and stresses ( ... ) that may increase their conflict potential" [32]. The intrinsic ability to overcome shocks was demonstrated to depend on demographic, social, and economic diversification of local contexts $[3,6,9,19,33,34]$. In this line of thinking, earlier works have characterized the intimate relationship between economic cycles, urbanization, and population dynamics by identifying a coherent socioeconomic profile for demographically 'resilient' or 'fragile' regions [35-37]. Assuming that homogeneous, balanced, and cohesive socioeconomic systems may better support an effective development path [38], resilience and local development are regarded as intimately linked concepts [39]. Local development has been increasingly interpreted under the 'resilience' lens, highlighting the importance of spatial (e.g., local-scale), temporal (e.g., long-term), and sectoral dimensions [40]. The interplay between these dimensions makes local systems' dynamics particularly complex and unpredictable [41-44]. In other words, a local system would be considered as 'demographically resilient' to the extent that its population dynamics are stable, or to the extent that it is able to embark on a transition from a given structure to another configuration and functioning [45-48].

By reconnecting recent literature on regional divides and operational approaches to the analysis of demographic resilience as an intrinsic characteristic of local systems, our study delineates distinctive, small-scale models of population growth (and decline) over a sufficiently long time scale [49-51]. As it is often considered an indicator of attractiveness (or collapse) of local communities, long-term population 
increase (or decrease) was assumed to be a proxy of demographic resilience [6,10,15], reflecting, e.g., the latent outcome of different socioeconomic processes [52-54] along urban-rural gradients-from urbanization and late industrialization to rural development (or shrinkage) [22,38,55]. Geographical gradients were often the bases of socioeconomic disparities among regions. European countries, and especially Mediterranean countries, provide examples of territorial divides and polarizations that were (and still are) alimented by differential economic structures [56-58], the unequal development of urban hierarchies, asymmetric market-state interactions [59], demographic change, and political instability [60]. Internal gaps have been even more intense in regions with traditional socio-cultural practices, limited access to infrastructure and reduced accessibility, aging, unemployment, and low-quality human capital [61-63].

Analysis of territorial divides in population dynamics has sometimes demised the role of external shocks shaping socioeconomic development at local scales [64-66]. Assuming a variable impact of these shocks across regions [67-69], socioeconomic systems were demonstrated to be more (or less) able to resist short-term disturbances depending on their demographic profiles [70-73]. Although demographic trends are the outcomes of the elementary processes of birth, death, and migration that have significant national and global drivers, regional population dynamics can be also influenced by (more or less) complex socioeconomic processes depending on the local background context $[6,15,19,27]$. By proposing a simplified classification of long-term population dynamics relevant to the analysis of demographic resilience, attractive places with a continuously expanding (resident) population were regarded as 'demographically resilient'; locations experiencing a persistent decline of population were considered fragile to external shocks [74]. Based on this assumption, the present study contributes to the identification and characterization of demographically resilient local systems by investigating population dynamics in more than 1000 municipalities of Greece between 1961 and 2011. Especially in Mediterranean Europe-and particularly in rural areas-use of elementary spatial domains such as municipalities may delineate homogeneous socioeconomic local systems better than other geographical partitions, even if their boundaries are typically administrative-and not completely functional.

Considering a sufficiently long and representative time window [75], demographic resilience in the study area was estimated on the basis of three scenarios: locations (i) attracting population, (ii) maintaining a constant population stock, and (iii) losing population. By explaining (apparent and latent) mechanisms that underlie population redistribution over larger regions [76-78], these three scenarios were assumed to be associated with different levels of demographic resilience at the local scale, reflecting more general socioeconomic conditions at the regional scale $[66,72,74]$. Our study benefited from a homogenized database derived from official statistics [79-81] and by referring to the common framework of Territorial Statistical Units proposed by EUROSTAT, the statistical office of the European Union. EUROSTAT published long-term municipal data (Local Administrative Unit (LAU)) 1 or 2 level, according with census' characteristics at the country scale) extracted and standardized from six censuses of the population and households between 1961 and 2011. Assuming local-scale population dynamics as an intrinsic property of socioeconomic local systems, investigation of long-term patterns of demographic growth and decline was also supposed to inform more precise strategies of regional management by adapting to multifaceted local contexts [82-84]. Based on this assumption, the study illustrates how a simple methodology built on wide-ranging indicators of population dynamics may provide informative tools for a comprehensive assessment of demographic resilience in local systems $[85,86]$, offering a knowledge base for comprehensive strategies that promote a 'holistic' development of districts and regions [87].

\section{Methodology}

\subsection{Study Area}

Partitioned in 13 administrative regions, more than 50 prefectures, and nearly 1030 municipalities, Greece extends 131,957 km² in Southeastern Mediterranean Europe (Figure 1). The study period 
encompassed the 50 years between 1961 and 2011. After continuous and non-linear demographic growth up to World War II, the present study investigates a time interval with a linear increase of resident population, from 8.5 million inhabitants in 1961 to less than 11 million inhabitants in 2011 [88-90]. While displaying heterogeneous trends at the regional scale, population density in Greece was rather low $\left(<100\right.$ inhabitants $/ \mathrm{km}^{2}$ )—with marked differentiations at the local scale, reflecting urban-rural divides, and an intense density gap, especially around the largest metropolitan regions, such as Athens and Thessaloniki [91-93]. These two regions hosted half of the Greek population in recent decades. Similarly to other countries in Southern Europe [94-96], aging, low fertility, and international migration (both emigration and immigration) were likely the most intense processes shaping population dynamics in the country [97-99].
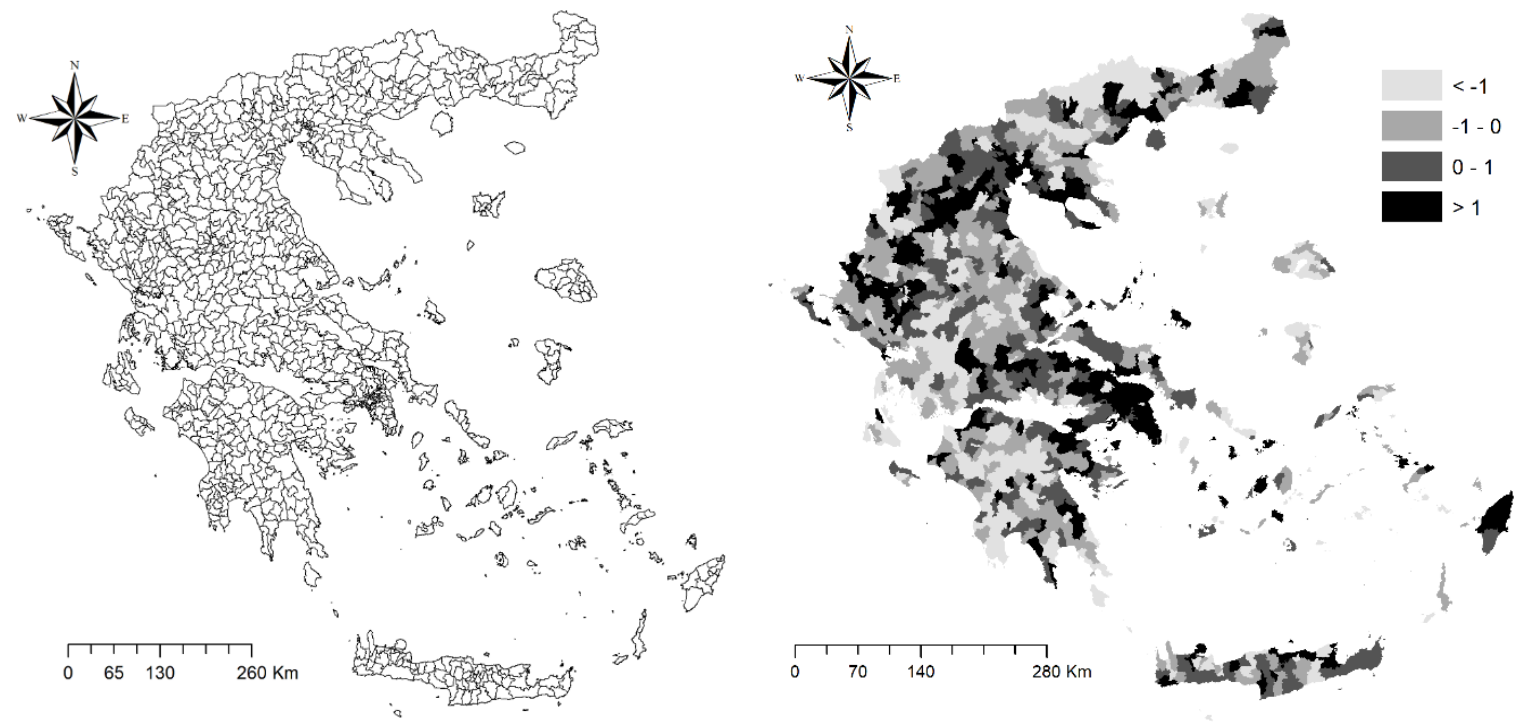

Figure 1. Maps illustrating the boundaries of Greek municipalities (left) and total population growth (percent annual rate) between 1961 and 2011 at the same spatial scale (right).

\subsection{Data and Variables}

The present study made use of Local Administrative Units (LAU-1 level), referring to the Nomenclature of Territorial Statistical Units (NUTS) as the elementary analysis's domain. In Greece, this administrative level reflects the geography of local communities, which are particularly homogeneous in rural areas $[69,70,72]$. This is because, in many cases, boundaries of local administrative units were originally traced by considering environmental constraints and territorial elements (e.g., mountains, rivers, lakes, road and railway infrastructures, harbors, accessibility, amenities), shaping the socioeconomic profiles of local communities in turn. Municipalities were therefore adopted as a spatial proxy of local systems in empirical studies using official statistics and covering long time intervals (e.g., [6,22,31,36]). Earlier studies carried out in rural districts of Southern Europe sharing similar characteristics with the study area have evidenced how municipalities are homogeneous local units that are appropriate for a quali-quantitative analysis of socioeconomic resilience.

Using quantitative approaches that integrate information from statistical indicators, field surveys, and interviews with local stakeholders, Kelly et al. [19] assessed the intrinsic level of socioeconomic resilience in a local community of Southern Italy corresponding with the population residing in the Gorgoglione municipality, Basilicata, which is considered as a particularly homogeneous spatial unit in terms of socioeconomic dynamics. With this perspective in mind, a refined framework was proposed by Salvia and Quaranta [67] and operationally applied to a specific socioeconomic context, the local community living in the Caggiano municipality (Campania, Italy). Ferrara et al. [22] expanded this interpretative framework to more than 30 municipalities in the Basilicata region in Southern Italy, which were considered as appropriate spatial units for analysis of 'fast' and 'slow' drivers 
of change and socioeconomic resilience of local systems. A similar framework was applied at the national scale in Greek municipalities [31] and, more specifically, in a rural district of Crete, Southern Greece, where extensive studies of resilience to external shocks were carried out by considering local municipalities as spatial proxies that delineate socio-environmental dynamics better than other reference units [43]. A similar approach was also applied—although in a partial fashion-in Spain [72], and a pilot study was finally carried out for three countries of Southern Europe (Spain, Italy, and Greece) using the same spatial scale under the same assumptions [85].

All these works also document the intrinsic opportunities of using municipal spatial units to exploit the particularly rich information associated with official statistics (mainly derived from population and housing censuses), which is clearly an additional reason supporting the adoption of these spatial domains in the analysis of demographic resilience. This information is especially reliable when municipal boundaries are stable over a sufficiently long time [72], indirectly allowing consolidation of specific socioeconomic traits according with the territorial context [74]. Taken together, our study was based on the rationale mentioned above. Homogeneous census data at the spatial scale of municipalities were provided by EUROSTAT for every ten years between 1961 and 2011. Population data were homogenized, taking account of changes in municipal boundaries all over Greece. These changes involved a rather small number of local units and mostly included fusion (or splitting) of neighboring units with comparable territorial characteristics, forming new local administrative entities where communities with similar demographic, social, and economic traits are settled. Based on the results of earlier studies $[72,74,85,91]$, these conditions seem to be appropriate for the analysis developed in our study and highlight the intrinsic trade-off between statistical availability and socioeconomic reliability of comparable population data over long terms $[70,81,88]$.

A simplified framework classifying Greek municipalities on the basis of long-term population trends was adopted with the aim of identifying 'demographically resilient' districts. Assuming districts that have continuously attracted population over a long time as 'demographically resilient' and districts continuously losing population over the same time period as 'demographically fragile', Greek municipalities were classified on the basis of the total number of decades with population growth or decline [74]. More specifically, having studied five decades (1961-1971, 1971-1981, 1981-1991, 1991-2001, and 2001-2011), 'resilient' and 'quasi-resilient' municipalities were identified when resident population increased over five or four decades, respectively. 'Fragile' or 'quasi-fragile' municipalities under persistent (or quasi-persistent) demographic shrinkage were identified when local population decreased over five or four decades, respectively [67]. Shrinking municipalities outline intense processes of depopulation, impacting the resilience potential of local communities [93].

This methodology was considered simple enough to be applied over vastly different socioeconomic and territorial contexts, maintaining the semantic linkage with the 'demographic resilience' concept [67]. However, it should be noted that the relationship between population dynamics and demographic resilience in local socioeconomic systems could be more articulated than expected [36,46,53], as it is molded by complex interactions and feedbacks [88]. Assuming the possible non-linear relationship between these two dimensions, we introduced a simplified classification of the level of demographic resilience based on four categories distinguishing characteristic, long-term population dynamics [85,87]. Together with the 'resilient' and 'fragile' classes, adopting 'quasi-resilient' and 'quasi-fragile' classes allow a refined understanding of less persistent population dynamics over long times in an attempt to incorporate the demographic variability characteristic of regional population patterns, at least in more recent decades [74]. To delineate spatial similarities in population dynamics, maps of Greek municipalities based on this classification were prepared using a shapefile provided by EUROSTAT. Population density (resident population per municipal area, inhabitants $/ \mathrm{km}^{2}$ ) and percent annual rate of population growth at five different time intervals (1961-1971, 1971-1981, 1981-1991, 1991-2001, and 2001-2011) were estimated at each spatial unit. 


\subsection{Data Analysis}

Taken as representative of local communities, especially in rural areas [80], Greek municipalities were profiled considering eight variables: (i) average elevation, (ii) population density, linear distance from (iii) Athens and (iv) Thessaloniki, (v) a dummy distinguishing coastal (1) and inland (0) municipalities, two dummies discriminating (vi) municipalities that coincide with the head town of an administrative region (NUTS-2 level) (1) or (vii) a prefecture (NUTS-3 level) (1) from the rest of Greek municipalities (0), and, finally, a dummy qualifying (viii) peri-urban municipalities (non-head towns in mainland Attica and Thessaloniki prefectures, respectively delineating the metropolitan regions of Athens and Thessaloniki). Under the hypothesis that geographical gradients in Mediterranean Europe are closely related with factors that affect (directly or indirectly) the spatial distribution of the resident population [100-103], basic territorial characteristics such as elevation, latitude, and distance from central cities and from the sea coast were assumed to reflect and summarize the socioeconomic profile of local communities in Greece [81,85,87].

Based on these premises, economic agglomeration and scale, accessibility, centrality, natural amenities, and the metropolitan hierarchy were considered important factors shaping demographic resilience in the studied socioeconomic context [19,31,36,43,72]. More specifically, population density was considered a proxy of economic agglomeration and scale factors; elevation was regarded as a proxy of accessibility; distances from Athens and Thessaloniki were considered as proxies of location centrality; proximity to the sea coast was taken as a proxy for natural amenities and tourism specialization. Dummies illustrating the administrative status of each studied municipality (head town of an administrative region/prefecture, or location belonging to a specific peri-urban area) finally provide indications on Greek metropolitan hierarchy, better delineating the urban-rural gradient in the country [74]. A pair-wise correlation analysis (based on Spearman non-parametric rank coefficients) was computed between each variable and the number of decades with population growth (or decline) over the whole study period [104]. Significant correlations were identified when $p<0.05$ after Bonferroni's correction for multiple comparisons [105].

\section{Results}

Greek municipalities were partitioned in different classes based on the number of decades with positive rates of population growth (Table 1). Nearly $10 \%$ of total municipalities (classified as 'fragile') experienced continuous population decline over the study period, with persistently negative rates ranging between $-0.8 \%$ and $-1.9 \%$ per year. This class was particularly homogeneous over time as far as growth rates are concerned, as the statistical distribution of the coefficients of variation around the average growth rates clearly illustrates. An additional 20\% of total municipalities (classified as 'quasi-fragile') experienced population decline over four out of five decades, with annual rates ranging between $-0.1 \%$ and $-1.6 \%$ and a particularly high spatial variability. Nearly $25 \%$ of municipalities were instead classified as 'resilient' or 'quasi-resilient', displaying positive rates of growth higher than $0.7 \%$ per year on average. Variability in growth rates was higher for municipalities belonging to the 'quasi-resilient' class, but lower for municipalities classified as strictly 'resilient'.

Table 1. Annual percent rate of population growth in Greek municipalities (average and coefficient of variation) by decade and demographic class (i.e., number of decades with positive growth rates).

\begin{tabular}{ccccccc}
\hline Class & \# Municipalities & $\mathbf{1 9 6 1 - 1 9 7 1}$ & $\mathbf{1 9 7 1 - 1 9 8 1}$ & $\mathbf{1 9 8 1 - 1 9 9 1}$ & $\mathbf{1 9 9 1 - 2 0 0 1}$ & $\mathbf{2 0 0 1 - 2 0 1 1}$ \\
\hline 0 ('fragile') & 105 & $-1.9(0.5)$ & $-1.0(0.7)$ & $-0.8(0.7)$ & $-0.8(0.8)$ & $-1.9(0.5)$ \\
1 ('quasi-fragile') & 236 & $-1.5(0.6)$ & $-0.4(2.2)$ & $-0.1(6.2)$ & $-0.3(5.0)$ & $-1.6(0.7)$ \\
2 & 265 & $1.0(1.3)$ & $0.5(6.9)$ & $-0.4(3.6)$ & $-0.1(2.2)$ & $-1.3(1.1)$ \\
3 & 161 & $-0.1(2.3)$ & $1.0(2.6)$ & $0.4(2.0)$ & $0.7(1.4)$ & $-0.1(9.1)$ \\
4 ('quasi-resilient') & 138 & $0.7(4.7)$ & $2.0(1.1)$ & $1.0(1.2)$ & $1.1(1.1)$ & $0.7(3.2)$ \\
5 ('resilient') & 129 & $3.0(1.1)$ & $3.1(0.9)$ & $2.1(1.1)$ & $1.7(1.1)$ & $1.3(1.2)$ \\
\hline
\end{tabular}


The average population density by demographic resilience class (Table 2) reflects the traditional polarization in urban and rural areas observed in Greece since the early 1950s. Resilient and quasi-resilient municipalities displayed moderate (or high) densities that increased continuously over time. Resilient municipalities shifted from 176 inhabitants $/ \mathrm{km}^{2}$ in 1961 to 476 inhabitants $/ \mathrm{km}^{2}$ in 2011 with moderate variability over space. Conversely, 'fragile' and 'quasi-fragile' municipalities had very low and low levels of population density (always below 50 inhabitants $/ \mathrm{km}^{2}$ ), respectively, decreasing further over the study period. Municipalities in 'quasi-resilient' and 'quasi-fragile' classes displayed a larger heterogeneity in population density compared with the strictly 'resilient' or 'fragile' classes, respectively.

Table 2. Population density (inhabitants $/ \mathrm{km}^{2}$ ) in Greek municipalities (average and coefficient of variation) by year and demographic resilience class.

\begin{tabular}{ccccccc}
\hline Class & $\mathbf{1 9 6 1}$ & $\mathbf{1 9 7 1}$ & $\mathbf{1 9 8 1}$ & $\mathbf{1 9 9 1}$ & $\mathbf{2 0 0 1}$ & $\mathbf{2 0 1 1}$ \\
\hline Fragile & $34(0.6)$ & $28(0.6)$ & $25(0.6)$ & $23(0.6)$ & $21(0.6)$ & $17(0.7)$ \\
Quasi-fragile & $41(8.2)$ & $34(8.6)$ & $33(8.8)$ & $32(8.6)$ & $31(8.6)$ & $26(8.8)$ \\
Quasi-resilient & $96(2.9)$ & $103(3.1)$ & $124(3.3)$ & $136(3.2)$ & $152(3.1)$ & $163(3.0)$ \\
Resilient & $176(2.1)$ & $230(2.0)$ & $300(1.8)$ & $362(1.7)$ & $424(1.6)$ & $479(1.6)$ \\
\hline
\end{tabular}

Based on these dynamics, the percent share of population residing in municipalities classified as 'resilient' and 'quasi-resilient' increased significantly over time (Table 3) from $17 \%$ to $35 \%$ of the Greek population (in the case of 'resilient' municipalities) and from 15\% to 19\% (in the case of 'quasi-resilient' municipalities). Inhabitants in 'fragile' municipalities amounted to $8 \%$ of the Greek population in 1961, declining rapidly to $3 \%$ in 2011. The same trend was observed in 'quasi-fragile' municipalities, hosting 17\% of the Greek population in 1961 and only 9\% in 2011.

Table 3. Percent share of population residing in Greek municipalities by year and demographic resilience class.

\begin{tabular}{ccccccc}
\hline Class & $\mathbf{1 9 6 1}$ & $\mathbf{1 9 7 1}$ & $\mathbf{1 9 8 1}$ & $\mathbf{1 9 9 1}$ & $\mathbf{2 0 0 1}$ & $\mathbf{2 0 1 1}$ \\
\hline Fragile & 8.4 & 6.5 & 5.3 & 4.6 & 4.0 & 3.2 \\
Quasi-fragile & 17.3 & 14.0 & 12.0 & 11.3 & 10.2 & 8.7 \\
Quasi-resilient & 14.9 & 15.3 & 16.5 & 17.2 & 18.0 & 19.3 \\
Resilient & 16.6 & 20.7 & 24.4 & 27.9 & 30.6 & 34.7 \\
\hline
\end{tabular}

The classification of municipalities proposed in this study outlines a mostly polarized and dynamic demographic context in Greece. The spatial distribution of municipalities classified as 'resilient' or 'fragile' (Figure 2) confirms the importance of geographical gradients, e.g., evidencing the inherent divide in medium-large urban areas and marginal rural districts, mostly inland. Resilient municipalities were primarily - but not exclusively-located in peri-urban districts of Athens (Attica) and Thessaloniki (Central Macedonia). A lower number of demographically resilient municipalities coincided with medium-size cities (e.g., Patras, Larisa, Chania, Ioannina, and Kozani) and coastal, low-density districts in the Cyclades and Dodecanese prefectures. Conversely, 'fragile' municipalities were systematically found in inland districts of both Northern and Central Greece, as well as in rural Peloponnese and Southern Crete, and in other mountain locations with poor accessibility. These spatial patterns were confirmed considering the spatial distribution of 'quasi-resilient' and 'quasi-fragile' municipalities. 

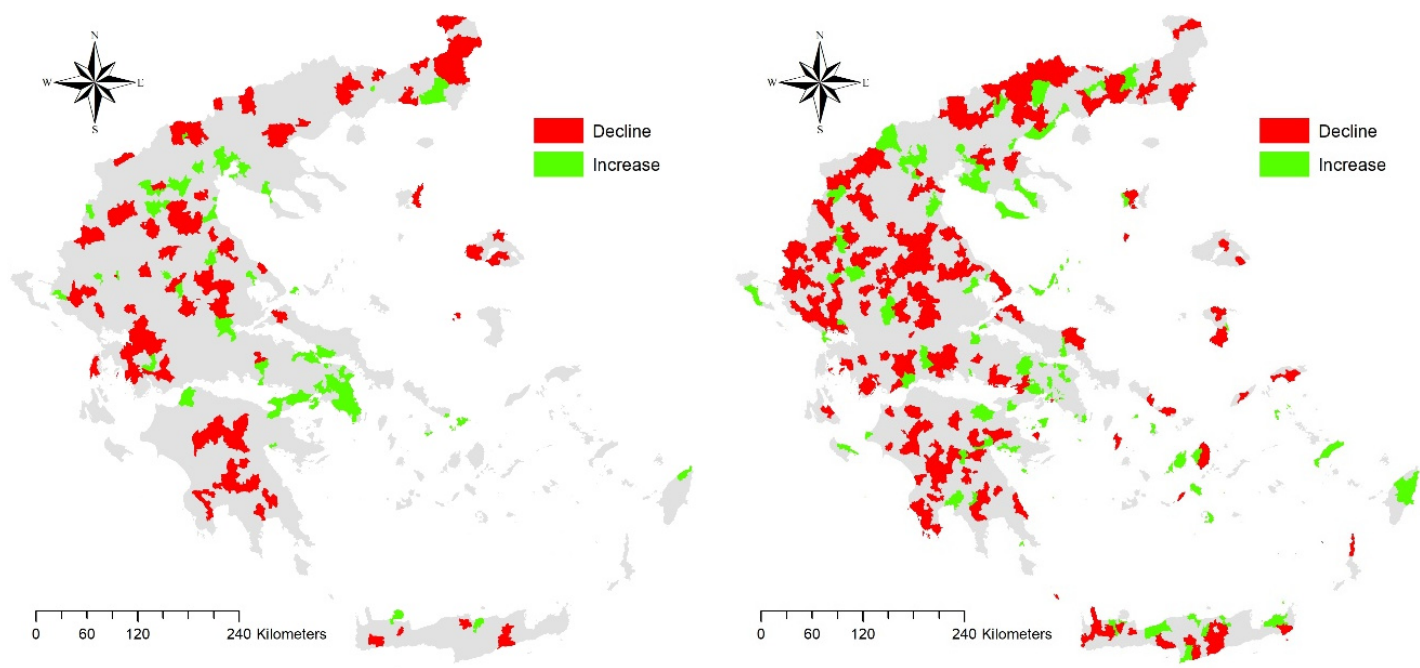

Figure 2. Spatial distribution of Greek municipalities by demographic resilience class; (left): 'resilient' (green) and 'fragile' (red) municipalities respectively experiencing five ('increase') and zero ('decline') decades with population growth; (right): 'quasi-resilient' (green) and 'quasi-fragile' (red) municipalities experiencing four ('increase') and one ('decline') decades with population growth.

The results of a correlation analysis (Table 4) indicate elevation and population concentration as the most effective variables for distinguishing demographically 'resilient' and 'fragile' municipalities. Being located along the sea coast was a feature differentiating strictly resilient from strictly fragile municipalities. The same pattern was observed for peri-urban locations, as well as for the distances from Athens and Thessaloniki. Regional head towns were more likely to be classified as quasi-resilient municipalities, while prefectural head towns were classified as resilient locations.

Table 4. Correlation analysis (non-parametric Spearman rank test) of the relationship between demographic resilience and selected indicators for Greek municipalities $(n=1034) ;+$ and - respectively indicate a significantly positive (or negative) relationship at $p<0.05$ (after Bonferroni's correction for multiple comparisons).

\begin{tabular}{ccccc}
\hline Indicator & Resilient & Quasi-Resilient & Quasi-Fragile & Fragile \\
\hline Elevation & - & - & + & + \\
Coastal area & + & & & - \\
Regional head & & & & \\
town & & & & - \\
Prefectural head & + & & & - \\
$\quad$ town & + & & & - \\
Peri-urban area & + & & & - \\
Distance from & + & & & - \\
Athens & + & & & - \\
Distance from & + & & & \\
Thessaloniki & + & & & \\
Population density & + & & &
\end{tabular}

\section{Discussion}

Socioeconomic transitions have shaped sequential waves of population growth and decline by accelerating (or depressing) urbanization and leveraging rural development (or shrinkage) [106-108]. Earlier studies have also documented how demographic change reflects socioeconomic processes resulting from urban-rural disparities [109,110]. Within this framework, a comprehensive investigation of population dynamics under different local contexts may delineate-likely better than other, more explicit, approaches-the role of territorial forces in altering economic structures and promoting social transformations [111-113]. Understanding how population dynamics shape (and are, in turn, 
influenced by) regional competitiveness and location attractiveness contributes to a refined analysis of local development mechanisms from a socioeconomic resilience perspective [114-116].

Accessibility and economic specialization were assumed to be significant forces shaping long-term demographic dynamics, leveraging radio-centric growth of settlements in urban regions and rural-to-urban migration with depopulation and land abandonment in strictly rural districts [117-119]. It was also demonstrated how differences in demographic dynamics between high-density municipalities and (peripheral) depopulated districts are nowadays still the main engine of economic polarizations and social divides in Southern Europe $[68,69,72,96]$. Based on these considerations, Greece is exemplificative of traditional Mediterranean societies with its polarized economy that reflects territorial disparities between coastal and inland districts. A thorough comparison of population dynamics over long time intervals [120] identifies sequential waves of urbanization and rural development that shape the level of socioeconomic resilience characteristic of local districts and regions [121].

While confirming the marked differences existing in regional population dynamics [122], the empirical results of our study outline a complex geography of demographically 'resilient' and 'fragile' areas in Greece. The classification proposed in this study reflects the main differentiation in urban and rural areas, which are more frequently classified, on average, as demographically 'resilient' and 'fragile'. Concerning rural districts, multiple forces, including industrial shrinkage, poor specialization in advanced services, and structural dependence on external funds in the primary sector, determined depopulation and the consequent fragility of inland, local communities all over Southern Europe [123-125]. Assuming that (place-specific) population structures and dynamics shape such processes [126], rural shrinkage in Greece and, more generally, in Mediterranean Europe has displayed different timing, intensity, and spatial directions among regions [127]. In Greece, depopulation processes have been spatially heterogeneous, contributing to the widening of the divide in demographically 'resilient' and 'fragile' areas. Following Reynaud et al. [100], "the municipalities that have experienced depopulation in a given decade are more likely to experience the same process in the following decades", outlining the importance of the cumulative effects of depopulation dynamics and indirectly confirming the theoretical validity and wide applicability of our approach to demographic resilience. "Simplified indicator systems derived from official statistics are increasingly required for a permanent monitoring of depopulation patterns and processes and a better understanding of spatial heterogeneity in the underlying drivers" [100].

However, the 'demographic resilience' polarization in urban and rural areas is not a rule of thumb, as the results of our study concerning the two intermediate classes ('quasi-resilient' and 'quasi-fragile' municipalities) demonstrate, evidencing, for instance, that some low-density municipalities are classified as demographically 'resilient' or 'quasi-resilient' in association with a more dynamic territorial profile (accessibility, amenities, infrastructures, openness to international networks and communities). The correlation analysis proposed in our study illustrates some possible factors shaping demographic resilience of local systems and demonstrates the relevance of such approaches when explaining the spatial patterns characteristic of resilient and more fragile districts.

At the same time, central cities and the surrounding high-density (urban) locations (Athens, Thessaloniki, Heraklion) have often displayed, especially in the last two to three decades, a lower attractiveness than accessible locations with lower density (e.g., peri-urban areas or coastal municipalities with dynamic economic sectors, e.g., tourism) [128]. These findings outline a particularly heterogeneous level of demographic resilience across urban locations that also emerged from descriptive statistics of population dynamics in 'quasi-resilient' municipalities compared with the 'resilient' ones. A continuous lowering of internal migration, declining immigration flows from abroad, low fertility, and aging suggest a thorough rethinking of present and future population trends and their intrinsic contributions to the socioeconomic resilience of local systems $[129,130]$. Considering social transitions, a better knowledge of new demographic scenarios opens up a reflection on the long-term mechanisms regulating population re-distribution over wider regions [131], contributing to the more precise identification of 'resilient' and 'fragile' districts and the delineation of opportunities for regional 
development policy [132]. Assuming comparative, long-term analyses of population distribution (and re-distribution) over space as necessary tools for informing appropriate policies for local systems' resilience [133], strategies promoting local development in demographically fragile regions should consider a polycentric expansion of human settlements, attracting population in smaller-while economically dynamic - centers, as an example of good practices for enhancing socioeconomic resilience [134].

Taking spatial heterogeneity in population patterns as a result of unbalanced local development paths [135], a refined investigation of the negative impact of socioeconomic downturns on local communities may shed light on both the intensity and direction of future population dynamics in post-crisis Mediterranean societies in light of local systems' resilience. Despite including simplified variables, the predictors considered in our study to profile 'resilient' (or 'fragile') municipalities are also revealed to be appropriate for a more extensive assessment and characterization of the intrinsic relation between local-scale population dynamics and the level of socioeconomic resilience at the regional scale in Europe. In this regard, depopulation - in contrast with the simultaneous growth of a few urban poles [136] -is seen as a particularly evident process of rural shrinkage with a possibly significant impact on the level of demographic resilience of local systems, as the empirical results from the Greek case suggest. In particular, the low densities together with a continuous population decline over a sufficiently long time horizon are symptoms of the demographic collapse of rural communities and the inability to respond appropriately to external shocks [137-140], suggesting "how rural shrinkage frequently underlies more volatile demographic dynamics" and indicating "the urgent need for more effective developmental policies against depopulation in hyper-rural districts" [74].

Based on these perspectives, our study contributes to the reconnection of long-term population dynamics with socioeconomic resilience theory, focusing on the specific dimension of 'demographic resilience'. While local systems classified as 'resilient' or 'fragile' - based on the criteria proposed in this study - display relatively clear socioeconomic traits, the local context underlying 'quasi-resilient' and 'quasi-fragile' municipalities are more heterogeneous, as our descriptive statistics may confirm. While they were introduced to evaluate the possible effect of non-linear population dynamics over time, the use of these two classes goes beyond a dichotomous classification of demographic resilience, assuring a more comprehensive analysis of spatial patterns characteristic of municipalities with 'intermediate' socioeconomic characteristics.

From a spatial planning perspective, a refined investigation of local systems belonging to such classes may stimulate further reflections on the specific contributions of resilience studies to local and regional developmental policies. Though it introduces a simplified approach to operationalizing population dynamics in a few classes of relevance for analysis of demographic resilience in local systems, our study may stimulate further research dealing with socioeconomic complexity by building on two separate visions: (i) the 'engineering' approach adopted to estimate the ability to recover from disturbances (under a 'single-equilibrium' analysis) and (ii) the socio-ecological approach, which refers to constant changes in a given system and assumes that the states of system equilibrium are usually unknown and, therefore, difficult to investigate in real systems. Refined methodological frameworks that (i) advance the 'engineering' vision with less mechanical mechanisms for interpreting a system's complexity and (ii) implement appropriate framework modeling complexity and non-linearity in the sequential states of system equilibriums are particularly appropriate to shed further light on demographic resilience.

\section{Conclusions}

Assuming local communities as complex adaptive systems, this study focused on 'demographic resilience' as a key dimension of socioeconomic resilience in local systems. The article introduces an empirical framework for quantitative analysis of 'demographic resilience' using statistical indicators and the intrinsic motivations underlying such an approach. Moreover, the article discusses the notion of the 'local system' from the socioeconomic perspective as well as the use of proxies to delineate 
homogeneous local systems by considering quantitative information available from specific data sources. In this way, our study aims at reconnecting demographic resilience with the broad issue of local development, providing an interpretative scheme that considers population dynamics as a proxy of local demographic resilience. Distinct population dynamics from growth to decline, covering the whole set of demographic responses along a density gradient-from largely urban to strictly rural locations-were considered here. The empirical results of this study contribute to profiling long-term population dynamics in more than 1000 Greek municipalities by delineating the intrinsic level of demographic resilience of local socioeconomic systems along basic geographical gradients. When assessing population (re)distribution over space and the implication for resilience of local communities, municipal units seem to be homogeneous and spatially detailed elementary domains under different socioeconomic contexts [141].

These findings highlight the relevance of a comparative analysis of long-term population dynamics for both positive and normative applications [142]. Although simplified and exploratory in its aims and scope, our proposal has the advantage of exploiting official statistics that are widely diffused in both advanced economies and emerging countries, thus contributing with a spatial approach in the field of resilience assessment in local socioeconomic systems. Future research should integrate the results of spatially explicit frameworks delineating more sophisticated approaches to regional demography by investigating the complex linkage between socioeconomic resilience and demographic dynamics more deeply and better characterizing the intrinsic profile of socioeconomic systems with different levels of demographic resilience [143]. Geo-referenced datasets with updated census information covering adequately long time windows are the necessary requisite of such investigations [144].

The results of our study indirectly confirm how non-linear development paths in complex adaptive systems are key for policymakers in complexity-led local growth and resilience thinking [145]. With this perspective in mind, rethinking territorial strategies and social policies enhancing the resilience of local communities and containing demographic shrinkage in rural districts are, therefore, imperative in the present economic setting [52]. Regional planning oriented towards a complex adaptive system thinking-moving from local to regional resilience-contributes to development paths that are together sustainable and resistant to disturbances [146-148]. Assuming that a planning approach oriented toward resilient thinking would secure local communities from the destructive impact of external shocks $[149,150]$, the notion of 'demographically resilient' districts seems to be an appropriate requisite in the identification of homogeneous socioeconomic dynamics that are resultingly particularly stable over space and balanced over time.

Author Contributions: Conceptualization, A.G.M. and P.C.; methodology, R.H.-C.-Z. and A.C.; software, L.S. and L.S.; validation, A.G.M. and A.C.; formal analysis, A.C. and L.S.; investigation, R.H.-C.-Z., C.H.-C.-Z., and P.C.; resources, R.H.-C.-Z.; data curation, A.C. and P.C.; writing-original draft preparation, L.S. and A.C.; writing-review and editing, P.C., R.H.-C.-Z., and C.H.-C.-Z.; visualization, A.G.M.; supervision, A.G.M.; project administration, A.G.M.; funding acquisition, A.G.M. and C.H.-C.-Z. All authors have read and agreed to the published version of the manuscript.

Funding: This research received no external funding.

Conflicts of Interest: The authors declare no conflict of interest.

\section{References}

1. Zolli, A.; Healy, A.M. Resilience: Why Things Bounce Back; Simon \& Schuster: New York, NY, USA, 2012.

2. Quinlan, A.E.; Berbés-Blázquez, M.; Haider, L.J.; Peterson, G.D. Measuring and assessing resilience: Broadening understanding through multiple disciplinary perspectives. J. Appl. Ecol. 2016, 53, 677-687. [CrossRef]

3. Walker, B.H.; Abel, N.; Anderies, J.M.; Ryan, P. Resilience, adaptability, and transformability in the Goulburn-Broken Catchment, Australia. Ecol. Soc. 2009, 14, 24. [CrossRef]

4. Östh,J.; Reggiani, A.; Galiazzo, G. Spatial economic resilience and accessibility: A joint perspective. Comput. Environ. Urban Syst. 2015, 49, 148-159. [CrossRef] 
5. Marchese, D.; Reynolds, E.; Bates, M.E.; Morgan, H.; Clark, S.S.; Linkov, I. Resilience and sustainability: Similarities and differences in environmental management applications. Sci. Total Environ. 2018, 613, 1275-1283. [CrossRef] [PubMed]

6. Schuetze, T.; Chelleri, L.; Salvati, L. Integrating resilience with urban sustainability in neglected neighborhoods: Challenges and opportunities of transitioning to decentralized water management in Mexico city. Habitat Int. 2015, 48, 122-130.

7. Bristow, G. Resilient regions: Re-'place'ing regional competitiveness. Camb. J. Reg. Econ. Soc. 2010, 3, $153-167$. [CrossRef]

8. Berkes, F.; Colding, J.; Folke, C. Navigating Social-Ecological Systems: Building Resilience for Complexity and Change; Cambridge University Press: Cambridge, UK, 2003.

9. Martin, R.; Sunley, P. On the notion of regional economic resilience: Conceptualization and explanation. J. Econ. Geogr. 2015, 15, 1-42. [CrossRef]

10. Rizzo, A. Declining, transition and slow rural territories in southern Italy. Characterizing the intra rural-divides. Eur. Plan. Stud. 2016, 24, 231-253. [CrossRef]

11. Doorn, N.; Gardoni, P.; Murphy, C. A multidisciplinary definition and evaluation of resilience: The role of social justice in defining resilience. Sustain. Resilient Infrastruct. 2019, 4, 112-123. [CrossRef]

12. Berkes, F.; Folke, C. Linking Social and Ecological Systems: Management Practices and Social Mechanisms for Building Resilience; Cambridge University Press: Cambridge, UK, 1998.

13. Adger, W.N. Social and ecological resilience: Are they related? Prog. Hum. Geogr. 2000, 24, 347-364. [CrossRef]

14. Harte, J. Human population as a dynamic factor in environmental degradation. Popul. Environ. 2007, 28, 223-236. [CrossRef]

15. Briguglio, L.; Cordina, G.; Farrugia, N.; Vella, S. Economic vulnerability and resilience: Concepts and measurements. Oxf. Dev. Stud. 2009, 37, 229-247. [CrossRef]

16. Walker, B.; Gunderson, L.; Kinzig, A.; Folke, C.; Carpenter, S.; Schult, L. A Handful of Heuristics and Some Propositions for Understanding Resilience in Social-Ecological Systems. Ecol. Soc. 2006, 11, 13. [CrossRef]

17. Brand, F.X.; Jax, K. Focusing the meaning(s) of resilience: Resilience as a descriptive concept and a boundary object. Ecol. Soc. 2007, 12, 23. [CrossRef]

18. Folke, C.; Carpenter, S.R.; Walker, B.; Scheffer, M.; Chapin, T.; Rockström, J. Resilience thinking: Integrating resilience, adaptability and transformability. Ecol. Soc. 2010, 15, 20. [CrossRef]

19. Kelly, C.; Ferrara, A.; Wilson, G.A.; Ripullone, F.; Nolè, A.; Harmer, N.; Salvati, L. Community resilience and land degradation in forest and shrubland socio-ecological systems: Evidence from Gorgoglione, Basilicata, Italy. Land Use Policy 2015, 1146, 11-20. [CrossRef]

20. Folke, C. Resilience: The emergence of a perspective for social-ecological systems analyses. Glob. Environ. Chang. 2006, 16, 253-267. [CrossRef]

21. Carpenter, S.; Walker, B.; Anderies, J.; Abel, N. From metaphor to measurement: Resilience of what to what? Ecosystems 2001, 4, 765-781. [CrossRef]

22. Ferrara, A.; Kelly, C.; Wilson, G.; Nolè, A.; Mancino, G.; Bajocco, S.; Salvati, L. Shaping the role of 'fast' and 'slow' drivers of change in forest-shrubland socio-ecological systems. J. Environ. Manag. 2016, 169, 155-166. [CrossRef]

23. Safarzynska, K.; Van Den Bergh, J.C.J.M. Demand-supply coevolution with multiple increasing returns: Policy analysis for unlocking and system transitions. Technol. Forecast. Soc. Chang. 2010, 77, 297-317. [CrossRef]

24. Ward, H. The co-evolution of regimes of accumulation and patterns of rule: State autonomy and the possibility of functional responses to crisis. New Political Econ. 2003, 8, 179-202. [CrossRef]

25. Kallis, G. Socio-environmental coevolution: Towards an analytical approach. Int. J. Sustain. Dev. World Ecol. 2007, 14, 9-19. [CrossRef]

26. Dentinho, T.P.; Serbanica, C. Space justice, demographic resilience and sustainability. Revelations of the evolution of the population hierarchy of the regions of Romania from 1948 to 2011. East. J. Eur. Stud. 2020, $11,27-44$.

27. Capdevila, P.; Stott, I.; Beger, M.; Salguero-Gómez, R. Towards a comparative framework of demographic resilience. Trends Ecol. Evol. 2020, 35, 776-786. [CrossRef] 
28. Larios, L.; Hallett, L.M.; Suding, K.N. Where and how to restore in a changing world: A demographic-based assessment of resilience. J. Appl. Ecol. 2017, 54, 1040-1050. [CrossRef]

29. Keenan, J.M.; Hauer, M.E. Resilience for whom? Demographic change and the redevelopment of the built environment in Puerto Rico. Environ. Res. Lett. 2020, 15, 074028. [CrossRef]

30. Fekete, A. Societal resilience indicator assessment using demographic and infrastructure data at the case of Germany in context to multiple disaster risks. Int. J. Disaster Risk Reduct. 2018, 31, 203-211. [CrossRef]

31. Cecchini, M.; Cividino, S.; Turco, R.; Salvati, L. Population Age Structure, Complex Socio-Demographic Systems and Resilience Potential: A Spatio-Temporal, Evenness-Based Approach. Sustainability 2019, 11, 2050. [CrossRef]

32. De Souza, R.M. Demographic resilience: Linking population dynamics, the environment, and security. SAIS Rev. Int. Aff. 2015, 35, 17-27. [CrossRef]

33. Gowdy, J.M. The social context of natural capital: The social limits to sustainable development. Int. J. Soc. Econ. 1994, 21, 43-55. [CrossRef]

34. Davies, S. Regional resilience in the 2008-2010 downturn: Comparative evidence from European countries. Camb. J. Regions Econ. Soc. 2011, 4, 369-382. [CrossRef]

35. Bocquier, P.; Costa, R. Which transition come first? Urban and demographic transitions in Belgium and Sweden. Demogr. Res. 2015, 33, 1297-1332. [CrossRef]

36. Salvati, L.; Carlucci, M.; Venanzoni, G. Recession, resilience, local labour markets: Wealthier is better? Lett. Spat. Resour. Sci. 2017, 10, 177-204. [CrossRef]

37. Portugali, J. Complexity theory as a link between space and place. Environ. Plan. A 2006, 38, 647-664. [CrossRef]

38. Carson, D.B.; Carson, D.A.; Porter, R.; Ahlin, C.Y.; Sköld, P. Decline, Adaptation or Transformation: New Perspectives on Demographic Change in Resource Peripheries in Australia and Sweden. Comp. Popul. Stud. 2016, 41, 3-4.

39. Berryman, A.A. Principles of Population Dynamics and Their Application; Stanley Thornes: Cheltenham, UK, 1999; ISBN 978-0-7487-4015-4.

40. Cohen, J.E. Human population: The next half century. Science 2003, 302, 1172-1175. [CrossRef]

41. Holling, C.S. Understanding the complexity of economic, ecological and social systems. Ecosystems 2001, 4, 390-405. [CrossRef]

42. Folke, C.; Hahn, T.; Olsson, P.; Norberg, J. Adaptive governance of social-ecological systems. Annu. Rev. Environ. Resour. 2005, 30, 441-473. [CrossRef]

43. Karamesouti, M.; Detsis, V.; Kounalaki, A.; Vasiliou, P.; Salvati, L.; Kosmas, C. Land-use and land degradation processes affecting soil resources: Evidence from a traditional Mediterranean cropland (Greece). Catena 2015, 132, 45-55. [CrossRef]

44. Van Den Bergh, J.C.J.M.; Stagl, S. Coevolution of economic behavior and institutions: Towards a theory of institutional change. J. Evol. Econ. 2003, 13, 289-317. [CrossRef]

45. Recanatesi, F.; Clemente, M.; Grigoriadis, S.; Ranalli, F.; Zitti, M.; Salvati, L. A fifty-years sustainability assessment of Italian Agro-forest Districts. Sustainability 2016, 8, 32. [CrossRef]

46. Pumain, D. Settlement systems in the evolution. Geogr. Ann. Ser. B Hum. Geogr. 2000, 82, 73-87. [CrossRef]

47. Cohen, J.E. Population growth and earth's human carrying capacity. Science 1995, 269, 341-346. [CrossRef] [PubMed]

48. Rodríguez-Pose, A.; Fratesi, U. Between Development and Social Policies: The Impact of European Structural Funds in Objective 1 Regions. Reg. Stud. 2004, 38, 97-113. [CrossRef]

49. Combes, P.P.; Duranton, G.; Overman, H.G. Agglomeration and the adjustment of the spatial economy. Pap. Reg. Sci. 2005, 84, 311-349. [CrossRef]

50. Gardiner, B.; Martin, R.; Tyler, P. Does spatial agglomeration increase national growth? some evidence from Europe. J. Econ. Geogr. 2011, 11, 979-1006. [CrossRef]

51. Tóth, G.; Nagy, Z. The world's economic centre of gravity. Reg. Stat. 2016, 6, 177-180.

52. Combes, P.P.; Duranton, G.; Gobillon, L. The identification of agglomeration economies. J. Econ. Geogr. 2011, 11, 253-266. [CrossRef]

53. Crescenzi, R.; Luca, D.; Milio, S. The geography of the economic crisis in Europe: National macroeconomic conditions, regional structural factors and short-term economic performance. Cambridge J. Regions Econ. Soc. 2016, 9, 13-32. [CrossRef] 
54. Chelli, F.; Rosti, L. Age and gender differences in Italian workers' mobility. Int. J. Manpow. 2002, 23, 313-325. [CrossRef]

55. Rosti, L.; Chelli, F. Self-employment among Italian female graduates. Educ. Train. 2009, 51, 526-540. [CrossRef]

56. Rosti, L.; Chelli, F. Higher education in non-standard wage contracts. Educ. Train. 2012, 54, 142-151. [CrossRef]

57. Sibly, R.M.; Hone, J.; Clutton-Brock, T.H. Population growth rate: Determining factors and role in population regulation. Introduction. Philos. Trans. R Soc. Lond B Biol. Sci. 2002, 357, 1149-1151. [CrossRef] [PubMed]

58. Fowler, C.W. Density Dependence as Related to Life History Strategy. Ecology 1981, 62, 602-610. [CrossRef]

59. Bauch, C.T. Wealth as a source of density dependence in human population growth. Oikos 2008, 117, 1824-1832. [CrossRef]

60. Berry, B.J.L. City Size Distributions and Economic Development. Econ. Dev. Cult. Chang. 1961, 9, 573-588.

61. Biasi, R.; Colantoni, A.; Ferrara, C.; Ranalli, F.; Salvati, L. In-between Sprawl and Fires: Long-term Forest Expansion and Settlement Dynamics at the Wildland-Urban Interface in Rome, Italy. Int. J. Sustain. Dev. World Ecol. 2015, 22, 467-475. [CrossRef]

62. Dyson, T. The Role of the Demographic Transition in the Process of Urbanization. Popul. Dev. Rev. 2011, 37, 34-54. [CrossRef]

63. Klasen, S.; Nestmann, T. Population, population density and technological change. J. Popul. Econ. 2006, 19, 611-626. [CrossRef]

64. Martínez-Filgueira, X.; Peón, D.; López-Iglesias, E. Intra-rural divides and regional planning: An analysis of a traditional emigration region (Galicia, Spain). Eur. Plan. Stud. 2017, 25, 1237-1255. [CrossRef]

65. Jackson, N. Sub-National Depopulation in Search of a Theory-Towards a Diagnostic Framework. New Zeland Popul. Rev. 2014, 40, 3-39.

66. Hospers, G.J.; Reverda, N. Managing Population Decline in Europe's Urban and Rural Areas; Springer: Heidelberg, Germany, 2015. [CrossRef]

67. Salvia, R.; Quaranta, G. Place-Based Rural Development and Resilience: A Lesson from a Small Community. Sustainability 2020, 9, 889. [CrossRef]

68. Haase, A.; Bernt, M.; Großmann, K.; Mykhnenko, V.; Rink, D. Varieties of shrinkage in European cities. Eur. Urban Reg. Stud. 2016, 23, 86-102. [CrossRef]

69. Gavalas, V.S.; Rontos, K.; Salvati, L. Who Becomes an Unwed Mother in Greece? Sociodemographic and Geographical Aspects of an Emerging Phenomenon. Popul. Space Place 2014, 20, 250-263. [CrossRef]

70. Morelli, V.G.; Rontos, K.; Salvati, L. Between suburbanisation and re-urbanisation: Revisiting the urban life cycle in a Mediterranean compact city. Urban Res. Pract. 2014, 7, 74-88. [CrossRef]

71. Russo, A.P.; Giné, D.S.; Albert, M.Y.P.; Brandajs, F. Identifying and Classifying Small and Medium Sized Towns in Europe. Tijdschr. Voor Econ. Soc. Geogr. 2017, 108, 380-402. [CrossRef]

72. Serra, P.; Vera, A.; Tulla, A.F.; Salvati, L. Beyond urban-rural dichotomy: Exploring socioeconomic and land-use processes of change in Spain (1991-2011). Appl. Geogr. 2014, 55, 71-81. [CrossRef]

73. Metcalf, C.J.E.; Pavard, S. Why evolutionary biologists should be demographers. Trends Ecol. Evol. 2007, 22, 205-212. [CrossRef]

74. Salvia, R.; Egidi, G.; Salvati, L.; Rodrigo-Comino, J.; Quaranta, G. In-between 'Smart' Urban Growth and 'Sluggish' Rural Development? Reframing Population Dynamics in Greece, 1940-2019. Sustainability 2020, 12, 6165. [CrossRef]

75. Sibly, R.M.; Hone, J. Population growth rate and its determinants: An overview. Phil. Trans. R Soc. Lond. B. 2002, 357, 1153-1170. [CrossRef]

76. Baker, J.; Ruan, X.; Alcantara, A.; Jones, T.; Watkins, K.; McDaniel, M.; Frey, M.; Crouse, N.; Rajbhandari, R.; Morehouse, J.; et al. Density-dependence in urban housing unit growth: An evaluation of the Pearl-Reed model for predicting housing unit stock at the census tract level. J. Econ. Soc. Meas. 2008, 33, 155-163. [CrossRef]

77. Beeson, P.E.; DeJong, D.N.; Troesken, W. Population growth in U.S. counties, 1840-1990. Reg. Sci. Urban Econ. 2001, 31, 669-699. [CrossRef]

78. Berliant, M.; Wang, P. Dynamic Urban Models: Agglomeration and Growth. In Contributions to Economic Analysis; Elsevier: Amsterdam, The Netherlands, 2004; Volume 266, pp. 531-581. ISBN 978-0-444-51481-3.

79. Kincses, Á.; Nagy, Z.; Tóth, G. Modelling the spatial structure of Europe. Reg. Stat. 2014, 4, 40-54. [CrossRef]

80. Salvati, L.; Carlucci, M. The economic and environmental performances of rural districts in Italy: Are competitiveness and sustainability compatible targets? Ecol. Econ. 2011, 70, 2446-2453. [CrossRef] 
81. Zambon, I.; Serra, P.; Sauri, D.; Carlucci, M.; Salvati, L. Beyond the 'Mediterranean city': Socioeconomic disparities and urban sprawl in three Southern European cities. Geogr. Ann. Ser. B Hum. Geogr. 2017, 99, 319-337. [CrossRef]

82. Oueslati, W.; Alvanides, S.; Garrod, G. Determinants of urban sprawl in European cities. Urban Stud. 2015. [CrossRef]

83. Partridge, M.D.; Rickman, D.S.; Ali, K.; Olfert, M.R. Do New Economic Geography agglomeration shadows underlie current population dynamics across the urban hierarchy? Pap. Reg. Sci. 2009, 88, 445-466. [CrossRef]

84. Portnov, B.A.; Schwartz, M. Urban Clusters as Growth Foci. J. Reg. Sci. 2009, 49, 287-310. [CrossRef]

85. Zambon, I.; Rontos, K.; Serra, P.; Colantoni, A.; Salvati, L. Population Dynamics in Southern Europe: A Local-Scale Analysis, 1961-2011. Sustainability 2019, 11, 109. [CrossRef]

86. Salvati, L.; Sateriano, A.; Grigoriadis, E. Crisis and the city: Profiling urban growth under economic expansion and stagnation. Lett. Spat. Resour. Sci. 2016, 9, 329-342. [CrossRef]

87. Ciommi, M.; Egidi, G.; Salvia, R.; Cividino, S.; Rontos, K.; Salvati, L. Population Dynamics and Agglomeration Factors: A Non-Linear Threshold Estimation of Density Effects. Sustainability 2020, 12, 2257. [CrossRef]

88. Salvati, L.; Serra, P. Estimating Rapidity of Change in Complex Urban Systems: A Multidimensional, Local-Scale Approach. Geogr. Anal. 2016, 48, 132-156. [CrossRef]

89. Di Feliciantonio, C.; Salvati, L. 'Southern' Alternatives of Urban Diffusion: Investigating Settlement Characteristics and Socio-Economic Patterns in Three Mediterranean Regions. Tijdschr. Voor Econ. Soc. Geogr. 2015, 106, 453-470. [CrossRef]

90. Carlucci, M.; Grigoriadis, E.; Rontos, K.; Salvati, L. Revisiting a Hegemonic Concept: Long-term 'Mediterranean Urbanization' in Between City Re-polarization and Metropolitan Decline. Appl. Spat. Anal. 2017, 10, 347-362. [CrossRef]

91. Rontos, K.; Grigoriadis, E.; Sateriano, A.; Syrmali, M.; Vavouras, I.; Salvati, L. Lost in protest, found in segregation: Divided cities in the light of the 2015 "Oxı" referendum in Greece. City Cult. Soc. 2016, 7, 139-148. [CrossRef]

92. Di Feliciantonio, C.; Salvati, L.; Sarantakou, E.; Rontos, K. Class diversification, economic growth and urban sprawl: Evidences from a pre-crisis European city. Qual. Quant. 2018, 52, 1501-1522. [CrossRef]

93. Frick, S.A.; Rodríguez-Pose, A. Change in urban concentration and economic growth. World Dev. 2018, 105, 156-170. [CrossRef]

94. Grafeneder-Weissteiner, T.; Prettner, K. Agglomeration and demographic change. J. Urban Econ. 2013, 74, 1-11. [CrossRef]

95. Beenstock, M.; Felsenstein, D. Marshallian theory of regional agglomeration. Pap. Reg. Sci. 2010, 89, 155-172. [CrossRef]

96. Salvati, L. The Dark Side of the Crisis: Disparities in per Capita income (2000-12) and the Urban-Rural Gradient in Greece. Tijdschr. Voor Econ. Soc. Geogr. 2016, 107, 628-641. [CrossRef]

97. Maloutas, T. Segregation, social polarization and immigration in Athens during the 1990s: Theoretical expectations and contextual difference. Int. J. Urban Reg. Res. 2007, 31, 733-758. [CrossRef]

98. Allen, J.; Barlow, J.; Leal, J.; Maloutas, T.; Padovani, L. Housing and Welfare in Southern Europe; Wiley: Hoboken, NJ, USA, 2008.

99. Cecchini, M.; Zambon, I.; Pontrandolfi, A.; Turco, R.; Colantoni, A.; Mavrakis, A.; Salvati, L. Urban sprawl and the 'olive' landscape: Sustainable land management for 'crisis' cities. Geo. J. 2019, 84, 237-255. [CrossRef]

100. Reynaud, C.; Miccoli, S. Depopulation and the Aging Population: The Relationship in Italian Municipalities. Sustainability 2018, 10, 1004. [CrossRef]

101. Bajocco, S.; De Angelis, A.; Salvati, L. A satellite-based green index as a proxy for vegetation cover quality in a Mediterranean region. Ecol. Indic. 2012, 23, 578-587. [CrossRef]

102. Bajocco, S.; Ceccarelli, T.; Smiraglia, D.; Salvati, L.; Ricotta, C. Modeling the ecological niche of long-term land use changes: The role of biophysical factors. Ecol. Indic. 2016, 60, 231-236. [CrossRef]

103. Kazemzadeh-Zow, A.; Shahraki, S.Z.; Salvati, L.; Samani, N.N. A spatial zoning approach to calibrate and validate urban growth models. Int. J. Geogr. Inf. Sci. 2017, 31, 763-782. [CrossRef]

104. Munafò, M.; Salvati, L.; Zitti, M. Estimating soil sealing rate at national level-Italy as a case study. Ecol. Indic. 2013, 26, 137-140. [CrossRef]

105. Bosker, M. Growth, Agglomeration and Convergence: A Space-time Analysis for European Regions. Spat. Econ. Anal. 2007, 2, 91-100. [CrossRef] 
106. Lemelin, A.; Rubiera-Morollón, F.; Gómez-Loscos, A. Measuring Urban Agglomeration: A Refoundation of the Mean City-Population Size Index. Soc. Indic. Res. 2016, 125, 589-612. [CrossRef]

107. Salvati, L.; Gemmiti, R.; Perini, L. Land degradation in Mediterranean urban areas: An unexplored link with planning? Area 2012, 44, 317-325. [CrossRef]

108. Lutz, W.; Sanderson, W.; Scherbov, S. The end of world population growth. Nature 2001, 412, 543-545. [CrossRef]

109. Lutz, W.; Qiang, R. Determinants of human population growth. Philos. Trans. R Soc. Lond. B Biol. Sci. 2002, 357, 1197-1210. [CrossRef]

110. Sato, Y.; Yamamoto, K. Population concentration, urbanization, and demographic transition. J. Urban Econ. 2005, 58, 45-61. [CrossRef]

111. Ciommi, M.; Chelli, F.M.; Salvati, L. Integrating parametric and non-parametric multivariate analysis of urban growth and commuting patterns in a European metropolitan area. Qual. Quant. 2019, 53, 957-979. [CrossRef]

112. Salvati, L.; Ciommi, M.T.; Serra, P.; Chelli, F.M. Exploring the spatial structure of housing prices under economic expansion and stagnation: The role of socio-demographic factors in metropolitan Rome, Italy. Land Use Policy 2019, 81, 143-152. [CrossRef]

113. Chelli, F.M.; Ciommi, M.; Emili, A.; Gigliarano, C.; Taralli, S. Assessing the Equitable and Sustainable Well-Being of the Italian Provinces. Int. J. Uncertain. Fuzziness Knowl. Based Syst. 2016, 24, 39-62. [CrossRef]

114. Gigliarano, C.; Chelli, F.M. Measuring inter-temporal intragenerational mobility: An application to the Italian labour market. Qual. Quant. 2016, 50, 89-102. [CrossRef]

115. Maloutas, T. Segregation and residential mobility: Spatially entrapped social mobility and its impact on segregation in Athens. European Urban and Regional Studies 2004, 11(3), 195-211. [CrossRef]

116. Chelli, F.; Gigliarano, C.; Mattioli, E. The impact of inflation on heterogeneous groups of households: An application to Italy. Econ. Bull. 2009, 29, 1276-1295.

117. Batabyal, A.A. The concept of resilience: Retrospect and prospect. Environ. Dev. Econ. 1998, 3, $235-239$. [CrossRef]

118. Zambon, I.; Colantoni, A.; Cecchini, M.; Mosconi, E.M. Rethinking sustainability within the viticulture realities integrating economy, landscape and energy. Sustainability 2018, 10, 320. [CrossRef]

119. Lamonica, G.R.; Chelli, F.M. The performance of non-survey techniques for constructing sub-territorial input-output tables. Pap. Reg. Sci. 2018, 97, 1169-1202. [CrossRef]

120. Petrakos, G.; Rodríguez-Pose, A.; Rovolis, A. Growth, Integration, and Regional Disparities in the European Union. Environ. Plan. A 2016. [CrossRef]

121. Buzar, S.; Ogden, P.; Hall, R.; Haase, A.; Kabisch, S.; Steinfiihrer, A. Splintering urban populations: Emergent landscapes of reurbanisation in four European cities. Urban Stud. 2007, 44, 651-677. [CrossRef]

122. Kabisch, N.; Haase, D. Diversifying European agglomerations: Evidence of urban population trends for the 21st century. Popul. Space Place 2011, 17, 236-253. [CrossRef]

123. Hoggart, K.; Paniagua, A. The restructuring of rural Spain? J. Rural Stud. 2001, 17, 63-80. [CrossRef]

124. Tapia, F.J.B.; Díez-Minguela, A.; Martinez-Galarraga, J. Tracing the Evolution of Agglomeration Economies: Spain, 1860-1991. J. Econ. Hist. 2018, 78, 81-117. [CrossRef]

125. Coleman, D.; Rowthorn, R. Who's afraid of population decline? A critical examination of its consequences. Popul. Dev. Rev. 2011, 37, 217-248. [CrossRef]

126. Doignon, Y.; Oliveau, S.; Bloss-Widmer, I. L'Europe méridionale depuis 20 ans: Dépeuplement, dépopulation et renouveau démographique. Espace Popul. Soc. 2016, 1, 1-22. [CrossRef]

127. Cuadrado-Ciuraneta, S.; Durà-Guimerà, A.; Salvati, L. Not only tourism: Unravelling suburbanization, second-home expansion and "rural" sprawl in Catalonia, Spain. Urban Geogr. 2017, 38, 66-89. [CrossRef]

128. De Rosa, S.; Salvati, L. Beyond a 'side street story'? Naples from spontaneous centrality to entropic polycentricism, towards a 'crisis city.' Cities 2016, 51, 74-83. [CrossRef]

129. Haase, A.; Kabisch, S.; Steinführer, A.; Bouzarovski, S.; Hall, R.; Ogden, P. Emergent spaces of reurbanisation: Exploring the demographic dimension of inner-city residential change in a European setting. Popul. Space Place 2010, 16, 443-463. [CrossRef]

130. Haase, D.; Haase, A.; Kabisch, N.; Kabisch, S.; Rink, D. Actors and factors in land-use simulation: The challenge of urban shrinkage. Environ. Model. Softw. 2012, 35, 92-103. [CrossRef]

131. Turok, I. Cities, Regions and Competitiveness. Reg. Stud. 2004, 38, 1069-1083. [CrossRef] 
132. Lamonica, G.R.; Recchioni, M.C.; Chelli, F.M.; Salvati, L. The efficiency of the cross-entropy method when estimating the technical coefficients of input-output tables. Spat. Econ. Anal. 2020, 15, 62-91. [CrossRef]

133. Ciommi, M.; Chelli, F.M.; Carlucci, M.; Salvati, L. Urban growth and demographic dynamics in southern Europe: Toward a new statistical approach to regional science. Sustainability 2018, 10, 2765. [CrossRef]

134. Salvati, L.; Carlucci, M.; Grigoriadis, E.; Chelli, F.M. Uneven dispersion or adaptive polycentrism? Urban expansion, population dynamics and employment growth in an 'ordinary' city. Rev. Reg. Res. 2018, 38. [CrossRef]

135. Petrakos, G.C. Urban Concentration and Agglomeration Economies: Re-examining the Relationship. Urban Stud. 1992. [CrossRef]

136. Alados, C.L.; Errea, P.; Gartzia, M.; Saiz, H.; Escós, J. Positive and Negative Feedbacks and Free-Scale Pattern Distribution in Rural-Population Dynamics. PLoS ONE 2014, 9, e114561. [CrossRef]

137. Beale, C.L. Rural depopulation in the United States: Some demographic consequences of agricultural adjustments. Demography 1964, 1, 264-272. [CrossRef]

138. Collantes, F.; Pinilla, V.; Sáez, L.A.; Silvestre, J. Reducing Depopulation in Rural Spain: The Impact of Immigration. Popul. Space Place 2014, 20, 606-621. [CrossRef]

139. Christiaans, T. On the implications of declining population growth for regional migration. J. Econ. 2017, 122, 155-171. [CrossRef]

140. Daugirdas, V.; Pociūtè-Sereikienè, G. Depopulation tendencies and territorial development in Lithuania. Reg. Stat. 2018, 8, 46-68. [CrossRef]

141. Salvati, L.; Ferrara, A.; Chelli, F. Long-term growth and metropolitan spatial structures: An analysis of factors influencing urban patch size under different economic cycles. Geogr. Tidsskr. Dan. J. Geogr. 2018, 118, 56-71. [CrossRef]

142. Salvati, L.; Guandalini, A.; Carlucci, M.; Chelli, F.M. An empirical assessment of human development through remote sensing: Evidences from Italy. Ecol. Indic. 2017, 78, 167-172. [CrossRef]

143. Ciommi, M.; Gigliarano, C.; Emili, A.; Taralli, S.; Chelli, F.M. A new class of composite indicators for measuring well-being at the local level: An application to the Equitable and Sustainable Well-being (BES) of the Italian Provinces. Ecol. Indic. 2017, 76, 281-296. [CrossRef]

144. Castagnetti, C.; Chelli, F.; Rosti, L. Educational performance as signalling device: Evidence from Italy. Econ. Bull. 2005, 9, 1-7.

145. Salvati, L.; Carlucci, M. A composite index of sustainable development at the local scale: Italy as a case study. Ecol. Indic. 2014, 43, 162-171. [CrossRef]

146. Melo, P.C.; Graham, D.J.; Noland, R.B. A meta-analysis of estimates of urban agglomeration economies. Reg. Sci. Urban Econ. 2009, 39, 332-342. [CrossRef]

147. Lauf, S.; Haase, D.; Kleinschmit, B. The effects of growth, shrinkage, population aging and preference shifts on urban development-A spatial scenario analysis of Berlin, Germany. Land Use Policy 2016, 52, 240-254. [CrossRef]

148. Rickman, D.S.; Wang, H. US regional population growth 2000-2010: Natural amenities or urban agglomeration? Pap. Reg. Sci. 2017, 96, S69-S90. [CrossRef]

149. Paulsen, K. Geography, policy or market? New evidence on the measurement and causes of sprawl (and infill) in US metropolitan regions. Urban Stud. 2014, 51, 2629-2645. [CrossRef]

150. Capello, R.; Camagni, R. Beyond optimal city size: An evaluation of alternative urban growth patterns. Urban Stud. 2000, 37, 1479-1496. [CrossRef]

(C) 2020 by the authors. Licensee MDPI, Basel, Switzerland. This article is an open access article distributed under the terms and conditions of the Creative Commons Attribution (CC BY) license (http://creativecommons.org/licenses/by/4.0/). 